\title{
Faktor Kesulitan Mahasiswa Program Studi Bahasa Korea Sekolah Vokasi UGM dalam Menjawab Soal TEVocS
}

\author{
Alfelia Nugky Permatasari', Yuni Wachid Asrori \\ Universitas Gadjah Mada' \\ alfelia.nugky.p@ugm.ac.id \\ Universitas Gadjah Mada ${ }^{2}$ \\ yuniwachid@ugm.ac.id
}

\begin{abstract}
Decree of Dean of Universitas Gadjah Mada Vocational School no. 10/UN1.SV/SK/2017 regarding graduation requirements for Universitas Gadjah Mada Vocational School students requires a minimum TEVocS score of 60 as one of the graduation requirements. This requirement burdens students, especially the ones other than English Language study program. To be able to graduate, a number of students even had to repeat their TEVocS until they get the required score. This study aims to identify the factors causing the difficulties of UGM Vocational School Korean Language study program students in answering TEVocS questions. This research used quantitative and qualitative approaches. A total of 44 Korean Language study program students became the objects of this study. Students were asked to complete TEVocS simulation and evaluate their performance, specifically related to the factors that caused them feel difficult in answering TEVocS questions. The evaluation was done using questionnaire. The finding shows that, in general, almost all Korean Language study program students found it difficult to answer TEVocS questions. Almost all Korean Language study program students admitted that they had difficulties in both listening and speaking sections of TEVocS. These difficulties were caused by a number of factors.
\end{abstract}

Keywords: TEVocS, difficulties, students, listening, speaking

\section{Intisari}

Surat Keputusan Dekan Sekolah Vokasi Universitas Gadjah mada no. 10/UN1.SV/SK/2017 tentang persyaratan kelulusan untuk mahasiswa Sekolah Vokasi Universitas Gadjah Mada mensyaratkan skor TEVocS minimal 60 sebagai salah satu persyaratan kelulusan. Persyaratan ini membebani mahasiswa, terutama mahasiswa selain program studi Bahasa Inggris. Untuk dapat lulus, sejumlah mahasiswa bahkan harus mengulang TEVocS mereka hingga mereka mencapai skor yang diminta. Penelitian ini bertujuan untuk mengidentifikasi faktor-faktor penyebab kesulitan yang dialami mahasiswa program studi Bahasa Korea Sekolah Vokasi UGM dalam menjawab soal TEVocS. Penelitian ini menggunakan pendekatan kuantitatif dan kualitatif. Sebanyak 44 mahasiswa program studi Bahasa Korea menjadi objek dalam penelitian ini. Siswa diminta untuk melakukan simulasi TEVocS dan mengevaluasi performa mereka, khususnya terkait faktor-faktor yang menyebabkan mereka merasa kesulitan dalam menjawab soal TEVocS. Evaluasi dilakukan dengan menggunakan kuesioner. Hasil yang ditemukan menunjukkan bahwa, secara umum, hampir seluruh mahasiswa program studi Bahasa Korea merasa kesulitan dalam menjawab soal TEVocS. Hampir seluruh mahasiswa program studi Bahasa Korea mengaku bahwa mereka mengalami kesulitan pada bagian listening dan speaking. Kesulitan-kesulitan ini disebabkan oleh sejumlah faktor.

Kata kunci: TEVocS, kesulitan, mahasiswa, listening, speaking 


\section{Pendahuluan}

Pada era revolusi industri keempat ini, di mana terjadi perubahan besar di berbagai bidang lewat perpaduan teknologi, manusia dituntut untuk memiliki kemampuan adaptasi yang tinggi (Wurianto, 2018). Kemampuan adaptasi yang dibutuhkan salah satunya adalah penguasaan bahasa asing, terutama bahasa Inggris. Pendidikan terkait pembelajaran bahasa asing yang tak luput dari arus perubahan ini pun telah bergeser baik dari segi teori, metode, hingga alat yang digunakan-dari yang sangat tradisional hingga yang tidak lepas dari pemanfaatan teknologi (Wienanda, dkk, 2018). Pada era pendidikan 4.0 seperti sekarang, kemampuan bahasa Inggris seorang siswa menjadi salah satu syarat penentu kesuksesan, baik selama masa studi maupun saat mereka telah meniti karir. Kemampuan bahasa Inggris di era disruptif ini diperlukan agar para siswa dapat beradaptasi juga berkompetisi di tengah-tengah kencangnya perubahan di berbagai bidang.

Pada praktik nyatanya, kemampuan bahasa Inggris seringkali menjadi salah satu syarat yang harus dipenuhi untuk dapat lolos baik dalam kompetisi studi, seperti masuk universitas ataupun mendaftar beasiswa tertentu, maupun kompetisi untuk memasuki dunia kerja. Berbagai English Proficiency Test, di antaranya seperti Test of English as a Foreign Language (TOEFL), Test of English for International Communication (TOEIC), dan International English Language Testing System (IELTS), digunakan untuk mengukur kemampuan bahasa Inggris seseorang. Tes ini merupakan suatu metode yang digunakan untuk mengukur kemampuan, pengetahuan, danperforma seseorang pada domain tertentu (Halim \& Ardiningtyas, 2018). Beragam tes tersebut memiliki fokus yang berbeda dalam mengukur kemampuan bahasa Inggris seseorang, tergantung tujuan penggunaan bahasa Inggris yang dibutuhkan nantinya. Untuk dapat berkompetisi di bidang yang dituju, seseorang tak jarang disyaratkan untuk memenuhi skor minimal pada salah satu tes kemampuan bahasa Inggris tersebut.

Persyaratan terkait kemampuan bahasa Inggris ini dianggap cukup menyulitkan bagi tidak sedikit orang. Beberapa penelitian telah membuktikan 
bahwa terdapat tidak sedikit kesulitan yang dialami seseorang dalam menjawab soal-soal English Proficiency Test. Kesulitankesulitan ini dapat dilihat pada Listening Comprehension TOEIC, misalnya yang diteliti oleh Meilinda \& Yuliah (2019). Sementara itu, pada TOEFL juga ditemukan kesulitan pada Listening Section (Chairuddin \& Ulfa, 2018), Reading Comprehension (Maizarah, 2019), dan TOEFL secara umum (Halim \& Ardiningtyas, 2018), (Lubis, dkk., 2019).

Pendidikan vokasi sendiri sebagai salah satu bagian dari sistem pendidikan nasional diharapkan mampu menciptakan dan mengembangkan sumber daya manusia yang tidak hanya dapat bekerja secara profesional di bidangnya, akan tetapi juga memiliki daya saing dalam dunia kerja (Rusmala, 2018). Di tengah-tengah arus disrupsi yang sangat dinamis sekarang ini, tentu daya saing yang dimaksud merupakan daya saing dunia kerja secara global. Terkait dengan hal ini, Sekolah Vokasi UGM pun tanpa terkecuali melihat pentingnya lulusan mereka untuk memiliki kemampuan bahasa Inggris yang baik. Untuk mengakomodasi hal tersebut, pada praktiknya, bahasa Inggris yang dimaksud lebih diarahkan pada interaksi lisan yang mencakup keterampilan menyimak dan berbicara dalam konteks kehidupan seharihari serta dunia kerja (Sari, 2017).

Sebagai upaya untuk menstandarisasi kemampuan bahasa Inggris lulusannya, Sekolah Vokasi UGM mensyaratkan calon lulusannya untuk mengantongi sertifikat English Proficiency Test. Persyaratan ini tertuang dalam Surat Keputusan Dekan Sekolah Vokasi Universitas Gadjah Mada no. 10/UN1.SV/SK/2017 tentang persyaratan kelulusan untuk mahasiswa Sekolah Vokasi Universitas Gadjah Mada mesyaratkan skor TEVocS minimal 60 sebagai salah satu persyaratan kelulusan. Bagi sebagian mahasiswa, persyaratan ini cukup memberatkan, terutama bagi mahasiswa yang berasal dari selain program studi Bahasa Inggris. Sejumlah mahasiswa bahkan harus mengulang TEVocS mereka untuk mendapatkan skor minimal yang diminta agar dapat lulus. Hal tersebut melatarbelakangi penelitian ini untuk menyelidiki faktor-faktor penyebab kesulitan yang dialami mahasiswa Sekolah Vokasi UGM, khususnya dari program studi Bahasa Korea, dalam menjawab soal TEVocS. 


\section{Metodologi Penelitian}

Untuk mengetahui faktor-faktor yang mempengaruhi kesulitan mahasiswa program studi Bahasa Korea Sekolah Vokasi UGM, digunakan dua pendekatan, yaitu kuantitatif dan kualitatif. Pendekatan kuantitatif digunakan untuk menyelidiki bagaimana pandangan mahasiswa program studi Bahasa Korea terhadap soal TEVocS secara umum. Pendekatan ini juga digunakan untuk melihat sejauh mana faktor-faktor yang menyebabkan seseorang merasa kesulitan mengerjakan soal English Proficiency Test pada umumnya, apakah juga dirasakan oleh objek dalam penelitian ini ketika mereka mengerjakan soal simulasi TEVocS. Sementara itu, pendekatan kualitatif digunakan untuk menyelidiki faktor lain yang menyebabkan mahasiswa program studi Bahasa Korea merasa kesulitan mengerjakan soal TEVocS.

Pada pengumpulan data, sebanyak 44 mahasiswa aktif program studi Bahasa Korea menjadi objek dalam penelitian ini. Mahasiswa tersebut berasal dari dua angkatan yang berbeda, 2017 dan 2018. Pada tahap awal, mereka diminta untuk mengerjakan simulasi TEVocS. Simulasi dilakukan menggunakan TEVocS Practice Test 1. Simulasi dilakukan secara serentak pada tanggal 3 Oktober 2019. Setelah simulasi selesai, mahasiswa yang bersangkutan diminta untuk mengevaluasi performa mereka selama tes, khususnya terkait hal-hal yang melatarbelakangi kesulitan mereka selama mengerjakan soal TEVocS. Evaluasi dilakukan dengan menggunakan kuesioner melalui google form yang tersedia pada laman https://forms.gle/QpPigUzMrfMKPVAZ8.

Kuesioner yang digunakan terdiri dari tiga bagian. Bagian pertama mencakup informasi responden diikuti latar belakang mereka terkait pengalaman mereka mengerjakan English Proficiency Test, seperti tes apa saja yang pernah mereka kerjakan. Pertanyaan mengenai gambaran umum apakah TEVocS sulit menurut mereka juga ditanyakan pada bagian ini. Bagian kedua berfokus pada pertanyaan seputar listening section. Pertanyaan pada bagian ini diawali dengan pertanyaan tertutup tentang pendapat mahasiswa secara umum terkait listening section TEVocS, yang diikuti dengan apakah faktorfaktor yang umumnya menyebabkan 
seseorang kesulitan saat mengerjakan English Proficiency Test juga mereka alami saat mengerjakan simulasi TEVocS. Kesulitan yang dimaksud didapatkan dari temuan Bingol, dkk (2014) terkait kesulitan yang dialami mahasiswa dalam proses listening khususnya pada English Proficiency Test, meliputi: kualitas materi rekaman; perbedaan budaya; aksen penutur; kosa kata yang tidak dikenal; serta panjang dan kecepatan menyimak. Faktorfaktor ini kemudian diperluas pula menggunakan temuan Meilinda dan Yuliah (2019) sehingga didapatkan total 11 faktor yang menyebabkan mahasiswa mengalami kesulitan mengerjakan soal listening pada English Proficiency Test. Bagian ini ditutup dengan pertanyaan terbuka mengenai faktor lain yang menyebabkan mereka kesulitan. Bagian ketiga kuesioner berfokus pada pertanyaan seputar speaking section. Seperti halnya pada listening section, speaking section terdiri dari tiga bagian. Bagian pertama berisi pertanyaan tertutup tentang pendapat mahasiswa secara umum terkait speaking section. Bagian kedua berisi pertanyaan tertutup tentang apakah faktor-faktor yang umumnya menyebabkan seorang kesulitan mengerjakan English Proficiency Test juga mereka rasakan saat mengerjakan TEVocS. Faktor-faktor terkait disusun berdasarkan Hermayawati (2010) yang menemukan beberapa faktor penyebab kesulitan mahasiswa dalam mempelajari bahasa Inggris secara umum: rasa terpaksa; rendahnya penguasaan materi/konsep dasar; kurangnya dukungan dari lingkungan; faktor lupa; kurangnya latihan. Pada penyusunan kuesioner untuk penelitian ini, faktor-faktor tersebut dijabarkan hingga didapatkan total 7 faktor yang menyebabkan mahasiswa kesulitan dalam menjawab soal speaking pada English Proficiency Test. Pertanyaan dalam kuesioner kemudian dilanjutkan dengan pertanyaan terbuka tentang faktor lain yang menyebakan mereka merasa kesulitan saat menjawab pertanyaan pada speaking section.

Jawaban yang didapatkan dari kuesioner kemudian dianalisis untuk melihat faktor-faktor apa saja yang menyebabkan mahasiswa program studi Bahasa Korea mengalami kesulitan dalam mengerjakan soal TEVocS. Hasil temuan dijabarkan secara deskriptif. Deskripsi temuan disajikan dengan menyertakan 
beberapa gambar sebagai ilustrasi. Lebih

jelasnya, metode penelitian diilustrasikan

pada Gambar 1.

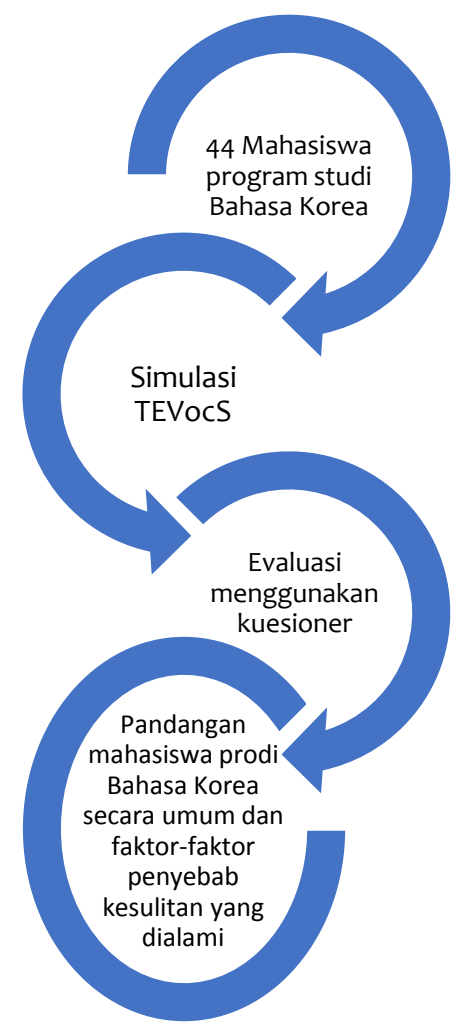

Gambar 1. Tahapan Metode Penelitian

Sumber: Penelitian Tahun 2019

\section{TEVocS}

Test of English for Vocational Students (TEVocS) adalah sebuah tes kemampuan bahasa Inggris yang didesain oleh program studi Bahasa Inggris Sekolah Vokasi UGM (Sekolah Vokasi Universitas Gadjah Mada, 2015). Tes yang menguji kemampuan menyimak (listening skill) dan berbicara (speaking skill) ini dibuat untuk mengukur kemampuan bahasa Inggris mahasiswa
Sekolah Vokasi. Berbeda dengan English Proficiency Test lainnya, TEVocS hanya mengukur kemampuan menyimak dan berbicara. Hal ini karena ke depannya, khususnya di dunia kerja, lulusan Sekolah Vokasi akan lebih berhubungan dengan hal-hal yang bersifat terapan. Dari sini tim penyusun TEVocS beranggapan bahwa kemampuan bahasa Inggris yang dibutuhkan mahasiswa Sekolah Vokasi 
adalah dapat menangkap informasi dan menyampaikan informasi menggunakan bahasa Inggris secara lisan dengan baik. Dalam pembuatannya, TEVocS juga didesain agar terasa familiar oleh mahasiswa Sekolah Vokasi UGM. Hal ini dapat dilihat dari hal-hal terkait baik pariwisata maupun landmark kota Yogyakarta yang disebut atau digunakan dalam soal TEVocS (Sekolah Vokasi UGM, 2019).
TEVocS terdiri dari dua bagian, yaitu listening section dan speaking section. Pada pelaksanaannya, tes kemampuan bahasa Inggris ini menghabiskan waktu kira-kira 45 menit. Listening section menghabiskan waktu kira-kira 30 menit. Sementara itu, speaking section menghabiskan waktu kirakira selama 15 menit. Pembagian waktu untuk masing-masing bagian tes selengkapnya dapat dilihat pada Tabel 1.

Tabel 1. Pembagian Waktu TEVocS

\begin{tabular}{|l|c|l|c|}
\hline Listening Section & 30 minutes & Speaking Section & 15 minutes \\
\hline Part I & Short conversation & Part I & Photograph/ Image \\
\hline Part II & Question-Response & Part II & Question-Response \\
\hline Part III & $\begin{array}{c}\text { Longer } \\
\text { Conversation }\end{array}$ & Part III & $\begin{array}{c}\text { Longer } \\
\text { Conversation }\end{array}$ \\
\hline Part IV & Long talks & \multicolumn{2}{|c}{} \\
\cline { 1 - 3 } & & &
\end{tabular}

Sumber: Sekolah Vokasi Universitas Gadjah Mada, 2015

\section{Listening Section TEVocS}

Listening section digunakan untuk mengukur kemampuan menyimak bahasa Inggris peserta tes. Pada saat tes berlangsung, peserta tes akan diperdengarkan audio berisi percakapan, pertanyaan dan/atau pernyataan pendek, dan monolog oleh penutur asli bahasa Inggris. Hal ini kemudian diikuti dengan beberapa pertanyaan terkait materi audio yang telah mereka dengar. Listening section pada TEVocS terdiri dari empat bagian, yaitu Short Conversation, QuestionResponse, Longer Conversation, dan Long Talks. Pada awal masing-masing bagian, diberikan petunjuk pendek untuk mengerjakan soal.

Bagian pertama (A) listening section TEVocS, Short Conversation, terdiri dari sepuluh percakapan pendek yang diikuti sepuluh pertanyaan. Kesepuluh 
pertanyaan tentang percakapan pendek ini masing-masing diikuti empat pilihan jawaban. Peserta tes hanya diperlihatkan pilihan jawaban tanpa ada teks transkrip percakapan maupun pertanyaan yang diajukan. Audio percakapan dan soal hanya diputar sekali tanpa pengulangan. Contoh tampilan buku uji bagian A listening section TEVocS dapat dilihat pada Gambar 2.

\section{LISTENING}

PART A

(Questions 1-10)

Direction: In this part of the test, you are going to hear short conversations between two people. The conversation won't be printed in your test book. The conversation won't be repeated. Choose the best answer to each question.

1. A. At a hospital.

B. In a restaurant.

C. In an office.

D. In a bank.

Gambar 2. Bagian A Listening Section TEVocS

Sumber: Sekolah Vokasi Universitas Gadjah Mada (C), 2015

Bagian kedua (B) listening section TEVocS, Question-Response, terdiri dari sepuluh pertanyaan dan/atau pernyataan pendek. Peserta tes diharapkan untuk memilih satu respon terbaik untuk masingmasing pertanyaan atau pernyataan pendek yang diberikan. Pada bagian ini tidak ditampilkan kepada peserta tes. Tiga pilihan jawaban dari masing-masing soal hanya dituturkan melalui audio. Selain audio yang hanya diputar sekali, hal ini juga mengharuskan peserta tes berkonsentrasi penuh untuk mendapatkan skor maksimal. Contoh tampilan buku uji bagian B listening section TEVocS dapat dilihat pada Gambar 3.

PART B
(Questions 11-20)

Directions: In this part of the test, you will hear a question or a statement followed by 3 responses. They will not be printed in the test book. Choose the best response to each question or statement.

11. Mark your answer on your answer sheet.

12. Mark your answer on your answer sheet.

Gambar 3. Bagian B Listening Section TEVocS

Sumber: Sekolah Vokasi Universitas Gadjah Mada @, 2015

Bagian ketiga (C) listening section TEVocS, Longer Conversation, terdiri dari tiga hingga empat percakapan yang sedikit lebih panjang dibandingkan percakapan pada bagian A. Masing-masing percakapan diikuti dua hingga empat pertanyaan. Terdapat sepuluh pertanyaan pada bagian C listening section TEVocS. Setiap pertanyaan diberikan empat pilihan jawaban yang ditampilkan pada buku uji. Baik percakapan, pertanyaan, dan pilihan 
jawaban hanya diputarkan sekali pada saat tes berlangsung. Contoh tampilan buku uji bagian $C$ listening section TEVocS dapat dilihat pada Gambar 4.

\section{PART C}

(Questions 21-30)

Directions: You will be listening to longer conversations. After each conversation, you will hear several questions. Read the four possible answers and choose the best one.

21. A. In an office.

B. In a shopping center.

C. In the theatre.

D. In the house.

Gambar 4. Bagian C Listening Section TEVocS

Sumber: Sekolah Vokasi Universitas Gadjah Mada (c), 2015

Sama halnya seperti bagian C, bagian keempat (D) listening section TEVocS, Long Talk, terdiri dari tiga hingga empat rekaman audio. Bedanya, audio yang diberikan berupa monolog. Masing-masing monolog juga diikuti dua hingga empat pertanyaan dengan total sepuluh pertanyaan. Setiap pertanyaan diberikan empat pilihan jawaban yang ditampilkan pada buku uji. Baik monolog, pertanyaan, dan pilihan jawaban hanya diputarkan sekali pada saat tes berlangsung. Contoh tampilan buku uji bagian D listening section TEVocS dapat dilihat pada Gambar 5.

\section{PART D}

(Question 31-40)

Directions: In this part of the test, you will hear several short talks. The talks will not be printed in the test book. You must listen very carefully as the talk will be played once only. In the test book, you will read two or three questions with four options about each talk. Choose the best answer.
31. A. April $9^{\text {th }} 2009$
B. April $19^{\text {th }} 2009$
C. April $19^{\text {th }} 2010$
D. April $29^{\text {th }} 2010$

Gambar 5. Bagian D Listening Section TEVocS

Sumber: Sekolah Vokasi Universitas Gadjah Mada @, 2015

\section{Speaking Section TEVocS}

Speaking section digunakan untuk mengukur kemampuan peserta tes dalam berbicara menggunakan bahasa Inggris. Dalam speaking section TEVocS, terdapat tiga tipe pertanyaan, yaitu Describe a Picture, Express an Opinion, dan Respond to Questions Using the Situation Provided. Pada tiap tipe pertanyaan, peserta tes diberikan petunjuk soal. Selain itu, dijelaskan pula waktu yang diberikan untuk persiapan dan menjawab soal secara lisan, masing-masing selama 60 detik. Peserta tes diharapkan dapat berbicara sebanyak mungkin sesuai waktu yang diberikan untuk menjawab masing-masing soal. 
Kejelasan ucapan dan keutuhan jawaban sesuai yang ditanyakan menjadi poin penting yang dibutuhkan untuk mendapatkan skor maksimal pada speaking section TEVocS. Tampilan awal buku uji speaking section TEVocS dapat dilihat pada

Gambar 6.

SPEAKING

Direction: This is the TEVocS Speaking Test. This test includes three (3) parts that measure different aspects of your speaking ability. The test lasts approximately 15 minutes.

\begin{tabular}{|c|l|l|}
\hline Question(s) & \multicolumn{1}{|c|}{ Task } & \multicolumn{1}{c|}{ Evaluation Criteria } \\
\hline 1 & Describe a picture & $\begin{array}{l}\text { pronunciation } \\
\text { intonation stress } \\
\text { grammar } \\
\text { vocabulary } \\
\text { cohesion }\end{array}$ \\
\hline 2 & Express an opinion & $\begin{array}{l}\text { pronunciation } \\
\text { intonation stress } \\
\text { grammar } \\
\text { vocabulary } \\
\text { cohesion } \\
\text { relevance of content } \\
\text { completeness of content }\end{array}$ \\
\hline 2 & $\begin{array}{l}\text { Respond to a situation and } \\
\text { questions }\end{array}$ & $\begin{array}{l}\text { pronunciation } \\
\text { intonation stress } \\
\text { grammar } \\
\text { vocabulary } \\
\text { cohesion } \\
\text { relevance of content } \\
\text { completeness of content }\end{array}$ \\
& & \\
& &
\end{tabular}

For each type of question, you will be given specific directions, including the time allowed for preparation and speaking.

It is to your advantage to say as much as you can in the time allowed. It is also important that you speak clearly and that you answer each question according to the directions.

\section{Gambar 6. Tampilan Awal Buku Uji Speaking Section TEVocS} Sumber: Sekolah Vokasi Universitas Gadjah Mada $\odot, 2015$

Pada bagian pertama speaking section TEVocS, Describe a Picture, peserta tes diberikan sebuah gambar. Peserta tes diharapkan untuk menjelaskan gambar yang mereka lihat. Untuk menjawab soal, peserta tes diberikan waktu 60 detik untuk persiapan. Setelah itu, mereka diberi waktu
60 detik untuk mendeskripsikan gambar yang mereka lihat. Semakin lengkap deskripsi yang mereka dapatkan, semakin tinggi pula skor yang didapatkan. Contoh tampilan buku uji bagian pertama Speaking section TEVocS dapat dilihat pada Gambar 7. 


\section{Question 41: Describe a Picture}

Directions: In this part of the test, you will describe the picture below in as much detail as you can. You will have 60 seconds to prepare and 60 seconds to speak about the picture.

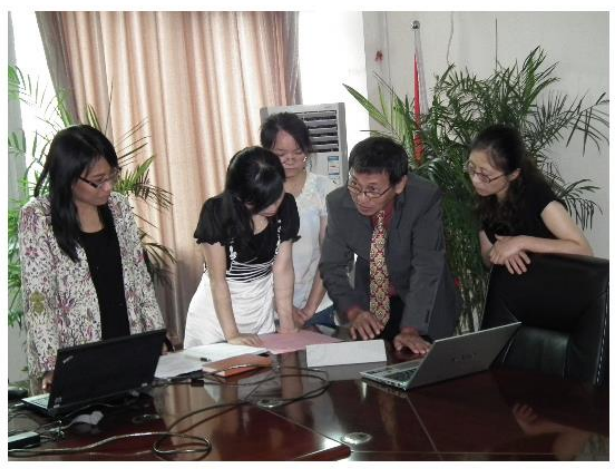

\section{Gambar 7. Bagian Pertama Speaking Section TEVocS}

Sumber: Sekolah Vokasi Universitas Gadjah Mada @, 2015

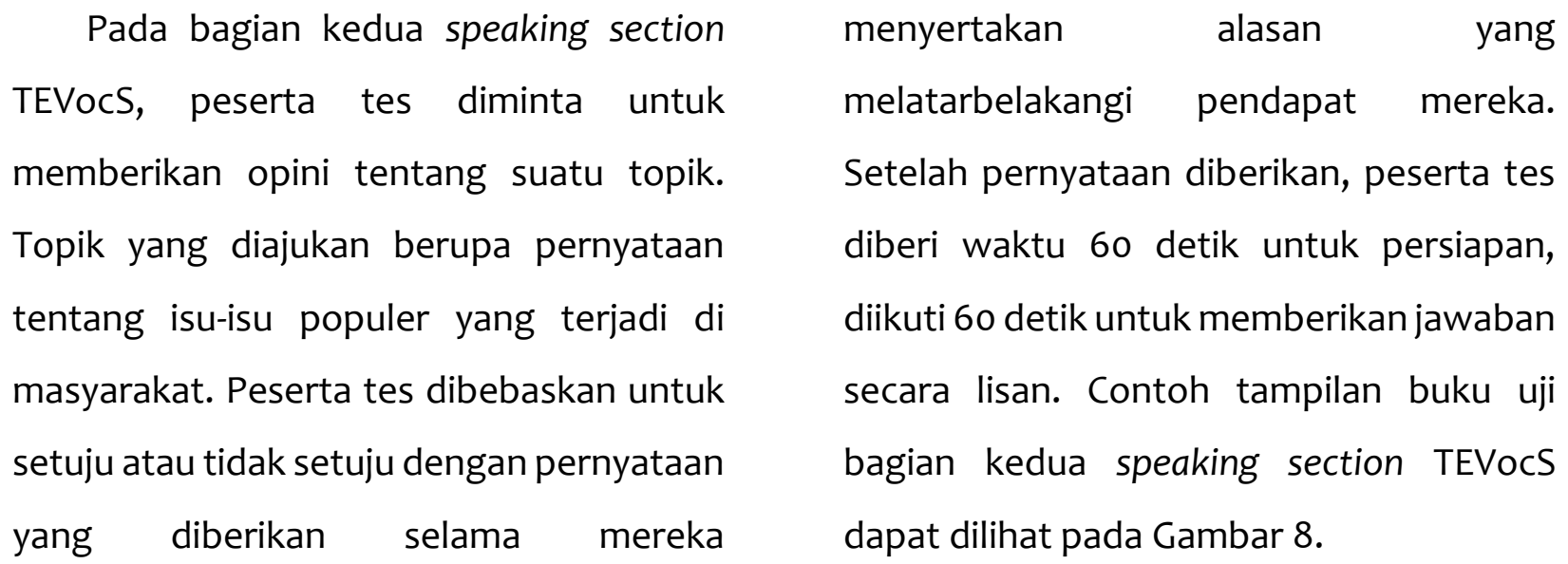

\section{Questions 42-43: Express an Opinion}

Directions: In this part of the test, you will give your opinion about a specific topic. Be sure to say as much as you can in the time allowed. You will have 60 seconds to prepare. Then you will have 60 seconds to speak to answer question 42 and 43.

\section{Question:}

(Narrator): While some schools are now against homework, as they state that homework can harm students in some ways, others still believe that the benefits far outweigh the possible shortcomings. What do you think are the benefits of assigning students to do homework? Give reasons or examples to support your opinion.

Gambar 8. Bagian Kedua Speaking Section TEVocS

Sumber: Sekolah Vokasi Universitas Gadjah Mada @, 2015 
Pada bagian ketiga speaking section TEVocS, Respond to Questions Using the Situation Provided, peserta tes diberikan informasi yang dapat berupa tabel maupun poster. Informasi yang diberikan dapat berupa jadwal, rencana perjalanan, maupun informasi pada poster konferensi. Setelah membaca informasi, peserta tes diberikan pertanyaan yang jawabannya tersedia di informasi yang telah diberikan sebelumnya. Untuk menjawab soal, peserta tes diberikan waktu 60 detik untuk persiapan, kemudian 60 detik untuk menjawab pertanyaan. Pertanyaan biasanya berupa seseorang yang menelepon untuk bertanya. Di sini peserta tes juga diuji kecakapan berkomunikasinya, secara spesifik dalam percakapan telepon. Contoh tampilan buku uji bagian ketiga speaking section TEVocS dapat dilihat pada

\section{Gambar 9.}

\section{Questions 44-45: Respond to questions using the situation provided}

Directions: In this part of the test, you will answer two (2) questions based on the information and situation provided. You will have 60 seconds to read the information before the questions begin. For each question, begin responding immediately after the proctor asks you to start. No additional preparation time is provided. You will have 60 seconds to respond to questions 44 and 45 .

\begin{tabular}{|c|c|}
\hline \multicolumn{2}{|r|}{ Saturday, 16 April } \\
\hline 11:00-19:00 & Collection of seminar materials by speakers and participants \\
\hline \multicolumn{2}{|r|}{ Sunday, 17 April } \\
\hline 11:00-19:00 & Collection of seminar materials by speakers and participants \\
\hline \multicolumn{2}{|r|}{ Monday, 18 April } \\
\hline 07:45-08:30 & Collection of seminar materials by overseas speakers and participants \\
\hline $08: 35-08: 45$ & Guests and participants are kindly requested to take their seats in the Auditorium \\
\hline \multirow[t]{2}{*}{ 09:00-09:40 } & OPENING CEREMONY \\
\hline & $\begin{array}{l}\text { Opening Address by the Guest of Honour H E Pehin Abu Bakar Apong } \\
\text { (Minister of Education, Brunei Darussalam, and President of the SEAMEO Council } \\
\text { Overview by Dr. Hannah Pillay (Chairman, Seminar Planning Committee) }\end{array}$ \\
\hline $09: 45-09: 55$ & Statement of Procedural Matters by Ms Chua (Seminar Secretariat) \\
\hline $10: 00-10: 30$ & Reception \\
\hline $10: 35-10.50$ & Highlights from the Publishers \\
\hline $10: 55-11: 55$ & $\begin{array}{l}\text { 1. Diagnosing Foreign Language Reading Proficiency for Learners of Different Age Groups } \\
\text { J Charles Alderson, Chair: Chan Yue Weng } \\
\text { 2. The Perils of Language Curriculum Development: Mistakes Were Made, Lessons } \\
\text { Learned } \\
\text { James Dean Brown, Chair: Tan Su Hwi }\end{array}$ \\
\hline $\begin{array}{c}12: 00-12: 45 I \\
12: 50-13: 35\end{array}$ & Lunch A / Lunch B + Viewing of Library Display and Materials Exhibition \\
\hline
\end{tabular}

Question:

(Narrator): Hello, this is Angela. I am calling about the conference scheduled for tomorrow, Monday, April the 18 $18^{\text {th }}$. I was told that I was supposed to be in the site on Saturday, but for some reasons I cannot make it. Could you tell me when the conference starts, is it Saturday or Monday? I don't want to miss the opening session by the Minister of Education, Brunei Darussalam; so, I do wish to be there before it starts. And could you also tell me the schedule in the first day?

Gambar 9. Bagian Ketiga Speaking Section TEVocS

Sumber: Sekolah Vokasi Universitas Gadjah Mada ๑, 2015 
Mahasiswa Program Studi Bahasa Korea dan TEVocS

Program studi Bahasa Korea merupakan salah satu dari tujuh program studi di Departemen Bahasa, Seni, dan Manajemen Budaya (DBSMB) Sekolah Vokasi UGM. Seperti mahasiswa program studi selain Bahasa Inggris di Sekolah Vokasi UGM pada umumnya, mahasiswa dari program studi Bahasa Korea mendapatkan mata kuliah bahasa Inggris di dua semester. Pada mata kuliah Bahasa Inggris I, mahasiswa dibekali kemampuan bahasa Inggris yang berfokus pada percakapan pada kehidupan sehari-hari. Selanjutnya, pada mata kuliah Bahasa Inggris II, mahasiswa dibekali kemampuan bahasa Inggris yang berfokus pada komunikasi di lingkungan kerja pada umumnya.

Evaluasi dari simulasi TEVocS menunjukkan bahwa $34.1 \%$ responden atau sebanyak 15 mahasiwa mengaku sudah pernah mengerjakan TEVocS sebelumnya. Kelima belas mahasiswa ini berasal dari angkatan 2017 yang menjelaskan bahwa mereka mendapat simulasi TEVocS sebagai ujian akhir di salah satu mata kuliah Bahasa Inggris pada semester awal. Persebaran mahasiswa antara yang pernah atau belum pernah mengerjakan TEVocS dapat dilihat pada Gambar 10.

Berapa kali mengambil TEVocS sebelum simulasi hari ini 44 responses

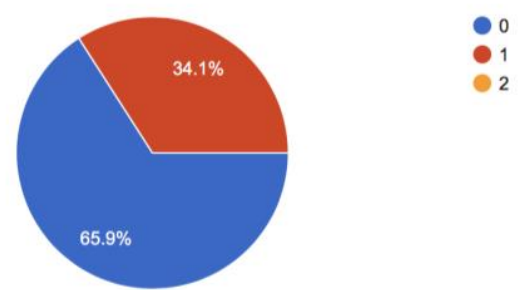

Gambar 10. Perbandingan Jumlah Mahasiswa yang Belum dan Sudah Pernah Mengerjakan TEVocS

Sumber: Data Penelitian tahun 2019

Meskipun hampir sepertiga responden mengaku telah melakukan simulasi TEVocS sebelumnya, hampir seluruh mahasiswa program studi Bahasa Korea mengaku kesulitan mengerjakan soal TEVocS. Setelah melakukan simulasi TEVocS secara serempak, 41 dari 44 mahasiswa program studi Bahasa Korea atau sekitar 93.2\% dari total responden masih mengaku kesulitan dalam mengerjakan TEVocS secara umum. Sebanyak 32 atau sekitar 72\% mengaku bahwa listening section TEVocS itu sulit, sedangkan sebanyak 41 mahasiswa atau sekitar 93.2\% mengaku bahwa speaking section TEVocS itu sulit. Temuan ini memperjelas kenyataan bahwa hampir 
seluruh mahasiswa program studi Bahasa Korea masih merasa kesulitan menyelesaikan soal-soal TEVocS. Selengkapnya, perbandingan ini dapat dilihat pada Gambar 11.

Setelah melakukan simulasi TEVocS, secara umum menurut $\mathrm{s}$ TEVocS itu ...

44 responses

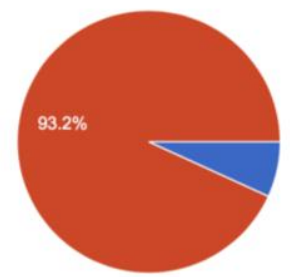

mudah sulit

Setelah melakukan simulasi TEVocS, menurut saya listening section dalam TEVocS itu ... 44 responses

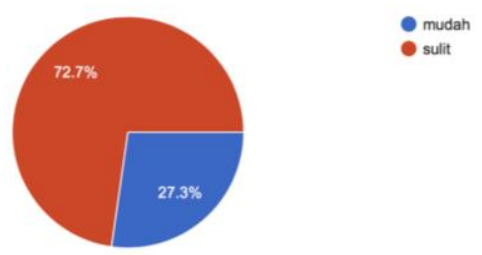

Setelah melakukan simulasi TEVocS, menurut saya speaking section dalam TEVocS itu ...

44 responses

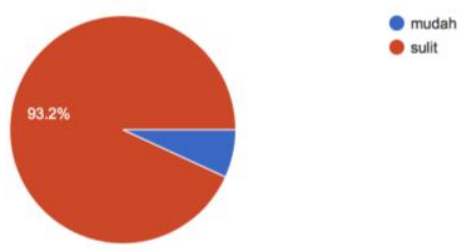

Gambar 11. Perbandingan Mahasiswa yang Merasa Kesulitan Mengerjakan TEVocS Sumber: Data Penelitian tahun 2019
Faktor Kesulitan Mahasiswa Program Studi Bahasa Korea dalam Menjawab Listening Section TEVocS

Dari empat bagian pada listening section TEVocS, bagian D (Long Talks) merupakan bagian yang dianggap paling sulit bagi mahasiswa program studi Bahasa Korea. Temuan ini dilihat dari sebanyak 22 mahasiswa atau 50\% dari total responden menganggap bagian $\mathrm{D}$ listening section sebagai bagian yang tersulit. Hal ini banyak dilatarbelakangi oleh jumlah informasi yang dianggap sulit diingat oleh peserta tes. Selanjutnya, diikuti bagian B (QuestionResponse) yang dianggap paling sulit bagi sepuluh mahasiswa atau sekitar $22.7 \%$ dari total responden. Hal ini banyak dipengaruhi oleh kecepatan pengucapan oleh penutur dalam audio dan kesulitan mahasiswa untuk berkonsentrasi ketika mendengarkan audio. Bagian yang dirasa tersulit selanjutnya yaitu bagian A (Short Conversation) dan bagian C (Long Conversation), masing-masing oleh sembilan mahasiswa dan tiga mahasiswa. Untuk lebih jelasnya, persebaran kesulitan yang dialami oleh mahasiswa program studi Bahasa Korea pada listening section TEVocS dapat dilihat pada Gambar 12. 
Menurut saya, bagian tersulit listening section ada pada .. 44 responses
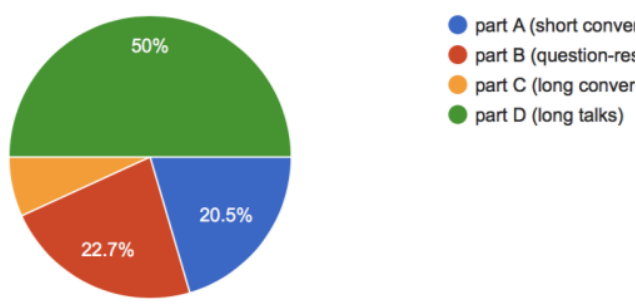

Gambar 12. Bagian yang Dianggap Tersulit pada Listening Section TEVocS

Sumber: Data Penelitian tahun 2019

Kesulitan yang dialami seseorang ketika mengerjakan listening section pada English Proficiency Test tentu dilatarbelakangi beberapa hal, seperti yang telah diteliti setidaknya oleh Bingol, dkk. (2014), Meilinda dan Yuliah (2019), dan Lubis, dkk. (2019). Dari evaluasi yang dilakukan oleh mahasiswa program studi Bahasa Korea setelah mengerjakan simulasi TEVocS, dapat diketahui bahwa beberapa faktor yang umumnya menyebabkan seseorang kesulitan saat mengerjakan English Proficiency Test, juga mereka alami saat mengerjakan simulasi TEVocS. Penulis mengurutkan dari yang tertinggi untuk faktor-faktor beserta jumlah mahasiswa yang merasa kesulitan mengerjakan soal listening section TEVocS pada Tabel 2 berikut.
Tabel 2. Faktor Penyebab Kesulitan Mahasiswa dalam Menjawab Soal Listening Section TEVocS

\begin{tabular}{|c|c|c|c|}
\hline No. & Faktor & $\begin{array}{c}\text { Jumlah } \\
\text { Mahasiswa }\end{array}$ & $\begin{array}{l}\text { Dalam } \\
\quad \%\end{array}$ \\
\hline 1 & $\begin{array}{l}\text { Ucapan penutur } \\
\text { yang relatif cepat }\end{array}$ & 44 & 100.0 \\
\hline 2 & $\begin{array}{l}\text { Aksen/dialek } \\
\text { penutur }\end{array}$ & 39 & 88.6 \\
\hline 3 & $\begin{array}{l}\text { Lemahnya } \\
\text { kemampuan } \\
\text { berkonsentrasi }\end{array}$ & 36 & 81.8 \\
\hline 4 & $\begin{array}{l}\text { Suara di sekeliling } \\
\text { yang mengganggu }\end{array}$ & 36 & 81.8 \\
\hline 5 & $\begin{array}{l}\text { Keterbatasan } \\
\text { kosakata bahasa } \\
\text { Inggris }\end{array}$ & 34 & $77 \cdot 3$ \\
\hline 6 & $\begin{array}{l}\text { Waktu merespon } \\
\text { atau menjawab } \\
\text { yang relatif singkat }\end{array}$ & 34 & $77 \cdot 3$ \\
\hline 7 & $\begin{array}{lr}\text { Informasi } & \text { yang } \\
\text { terlalu } & \text { banyak } \\
\text { dalam } & \text { waktu } \\
\text { singkat } & \end{array}$ & 33 & 75.0 \\
\hline 8 & $\begin{array}{l}\text { Kualitas } \\
\text { rekaman/audio }\end{array}$ & 29 & 65.9 \\
\hline 9 & $\begin{array}{l}\text { Kekurangpahaman } \\
\text { akan topik yang } \\
\text { dibicarakan }\end{array}$ & 25 & 56.8 \\
\hline 10 & $\begin{array}{l}\text { Daya ingat yang } \\
\text { lemah }\end{array}$ & 23 & 52.3 \\
\hline 11 & $\begin{array}{l}\text { Kondisi fisik yang } \\
\text { kurang baik }\end{array}$ & 14 & 32.6 \\
\hline
\end{tabular}

Sumber: Data Penelitian tahun 2019

Temuan dari penelitian ini menunjukkan bahwa seluruh mahasiswa program studi Bahasa Korea menganggap kecepatan penutur sebagai faktor penyebab mereka merasa kesulitan menjawab soal pada listening section 
TEVocS. Faktor ini diikuti oleh aksen/dialek penutur pada rekaman audio listening section TEVocS. Kenyataan bahwa keseluruh mahasiswa program studi Bahasa Korea merupakan orang Indonesia dengan bahasa Indonesia sebagai bahasa komunikasi sehari-hari menyebabkan mereka tidak biasa mendengarkan tuturan berbahasa Inggris. Selama prosen belajar di kelas pun mereka tentu lebih terbiasa mendengarkan tuturan berbahasa Korea daripada mendengarkan tuturan berbahasa Inggris. Hal ini menyebabkan mereka merasa kesulitan mengikuti audio pada listening section TEVocS yang tentu diperlukan untuk menjawab soal dengan baik.

Faktor lain yang dianggap menyulitkan mahasiswa program studi Bahasa Korea merasa kesulitan menjawab soal listening section TEVocS yaitu lemahnya kemampuan konsentrasi dan suara di sekeliling yang mengganggu selama tes berlangsung. Jika dilihat, kedua faktor ini saling berkaitan. Simulasi yang dilakukan saat pengambilan data memang dilakukan bukan di laboratorium, layaknya pelaksanaan TEVocS yang sebenarnya, melainkan di ruang kelas biasa. Hal ini dapat menyebabkan mahasiswa merasa kesulitan berkonsentrasi selama tes berlangsung. Apalagi mengingat kecakapan yang diukur adalah kemampuan menyimak, yang membutuhkah konsentrasi lebih terutama jika distraksi berupa suara ada di sekeliling mereka.

Faktor selanjutnya yang dianggap menyulitkan bagi mahasiswa program studi Bahasa Korea dalam menjawab soal listening section TEVocS yaitu keterbatasan kosakata bahasa Inggris yang dimiliki. Tidak dapat diingkari bahwa penguasaan kosakata memegang peran penting dalam baik dalam pembelajaran maupun penguasaan bahasa (Alqahtani, 2015). Dengan memiliki jumlah kosakata yang memadai, seorang pembelajar bahasa tertentu akan lebih mudah memahami tuturan-tuturan yang menggunakan bahasa terkait. Kenyataan ini bertolak belakang dengan keadaan mahasiswa program studi Bahasa Korea. Mereka menganggap kosakata bahasa Inggris mereka terbatas dikarenakan jarangnya mendapat paparan bahasa Inggris dalam kehidupan sehari-hari. Dari pendidikan formal yang mereka dapatkan di Sekolah Vokasi, mahasiswa program studi Bahasa 
Korea hanya mendapatkan mata kuliah Bahasa Inggris selama dua semester, masing-masingnya satu pertemuan dalam seminggu selama 100 menit.

Faktor lainnya yang dianggap menyulitkan bagi mahasiswa program studi Bahasa Korea dalam listening section TEVocS adalah waktu merespon atau menjawab yang relatif singkat. Hal ini berhubungan dengan faktor lain yang mengikuti yaitu terlalu banyaknya informasi yang diberikan dalam waktu singkat. Terdapat jeda +/- enam detik dari penyebutan pilihan jawaban terakhir hingga masuk ke soal selanjutnya. Hal ini dianggap masih relatif terlalu singkat bagi mahasiswa program studi Bahasa Korea untuk mencerna materi audio, memahami soal, kemudian memutuskan jawaban yang tepat untuk soal terkait. Hal ini kiranya juga dilatarbelakangi oleh kurangnya paparan bahasa Inggris yang didapatkan mereka sehari-hari.

Kualitas rekaman/audio menjadi faktor lain yang juga dianggap mahasiswa program studi Bahasa Korea merasa kesulitan menjawab soal listening section TEVocS. Jika dihubungkan dengan faktor kurangnya kosakata Bahasa Inggris yang dimiliki mahasiswa program studi Bahasa Korea, faktor ini dapat menyebabkan mereka kurang paham akan topik yang dibicarakan. Belum lagi jika hal ini masih diperburuk oleh faktor daya ingat yang lemah, di mana daya ingat yang baik sangat diperlukan peserta tes untuk dapat menjawab bagian $C$ dan $D$ listening section TEVocS dengan baik. Tentu akumulasi faktor-faktor ini dapat semakin menyulitkan mereka dalam menjawab soalsoal listening section TEVocS.

Faktor terakhir yang umumnya menyebabkan seseorang kesulitan menjawab soal listening pada English Proficiency Test adalah kondisi fisik yang kurang baik. Faktor ini diakui oleh sekitar sepertiga, tepatnya 14 dari 44 mahasiswa program studi Bahasa Korea, sebagai salah satu faktor yang membuat mereka merasa kesulitan menjawab soal listening section TEVocS. Kondisi fisik yang kurang baik cukup berpengaruh padda kemampuan konsentrasi seseorang. Ketika kondisi fisik seseorang sedang kurang baik, besar kemungkinan akan menyulitkan mereka dalam berkonsentrasi. Hal ini tentu kurang menguntungkan, khususnya bagi seseorang yang harus mengerjakan soal- 
soal dalam English Proficiency Test pada umumnya, termasuk listening section pada TEVocS.

Selain faktor-faktor di atas, terdapat dua faktor lain yang disebutkan oleh sejumlah mahasiswa program studi Bahasa Korea menjadi penyebab kesulitan mereka dalam mengerjakan soal listening section TEVocS. Salah satu faktor tersebut adalah percakapan yang hanya diputar sekali, yang juga sejalan dengan temuan Underwood dalam Meilinda \& Yuliah (2019). Faktor lainnya yang disebutkan adalah belum belajar atau kurangnya persiapan sebelum simulasi atau tes dilakukan. Sebagai mahasiswa yang lebih banyak belajar danmendapat paparan bahasa Korea sehari-hari, persiapan dianggap dibutuhkan oleh mahasiswa tersebut untuk sekiranya dapat membiasakan dirinya kembali dengan bahasa Inggris yang harapannya dapat meningkatkan performa mereka dalam menjawab soal TEVocS pada umumnya.

\section{Faktor Kesulitan Mahasiswa}

Program Studi Bahasa Korea dalam Menjawab Speaking Section TEVocS

Dari tiga bagian pada speaking section TEVocS, bagian pertama (Describing
Picture) dianggap paling sulit bagi mahasiswa program studi Bahasa Korea. Temuan ini dilihat dari sebanyak 20 dari total 44 mahasiswa, atau sekitar $45.5 \%$ dari total responden, menganggap bagian ini sebagai bagian tersulit. Bagian dari speaking section TEVocS yang dirasa tersulit selanjutnya adalah bagian kedua (Giving Opinion), oleh 14 mahasiswa atau sekitar 31.8\% dari total responden. Bagian terakhir dari speaking section TEVocS yang dirasa tersulit adalah bagian ketiga (Answering Question Based on Information Provided), oleh 10 mahasiswa atau sekitar $22.7 \%$ dari total responden. Untuk lebih jelasnya, urutan soal speaking section TEVocS tersulit menurut mahasiswa program studi Bahasa Korea dapat dilihat pada Gambar 13.

Menurut saya, bagian tersulit speaking section ada pada ... 44 responses

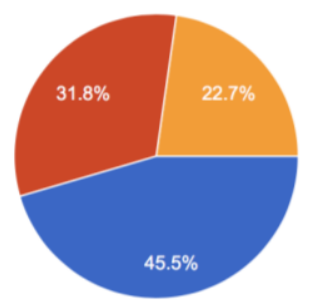

Question 41 (describing picture)

Question 42-43 (giving opinion)

Question 44-45 (answering question based on information provided)

Gambar 13. Bagian yang Dianggap Tersulit pada Speaking Section TEVocS

Sumber: Data Penelitian Tahun 2019

Kesulitan yang dialami seorang peserta English Proficiency Test ketika 
mengerjakan speaking section tentu dipengaruhi oleh beberapa hal. Dari evaluasi yang dilakukan oleh mahasiswa program studi Bahasa Korea setelah mengerjakan simulasi TEVocS, didapatkan faktor-faktor yang melatarbelakangi kesulitan yang mereka alami ketika diurutkan berdasarkan banyaknya jumlah mahasiswa, faktor-faktor ini beserta banyaknya mahasiswa yang merasa kesulitan mengerjakan soal speaking section TEVocS dikarenakan faktor-faktor tersebut selengkapnya dapat dilihat pada Tabel 3. melakukan simulasi TEVocS. Setelah

Tabel 3. Faktor Penyebab Kesulitan Mahasiswa dalam Menjawab Soal Speaking Section TEVocS

\begin{tabular}{|c|l|c|c|}
\hline No. & \multicolumn{1}{|c|}{ Faktor } & \multicolumn{1}{|c|}{$\begin{array}{c}\text { Jumlah } \\
\text { Mahasiswa }\end{array}$} & $\begin{array}{c}\text { Dalam } \\
\%\end{array}$ \\
\hline 1 & Kurangnya latihan berbicara menggunakan bahasa Inggris & 43 & 97.7 \\
\hline 2 & $\begin{array}{l}\text { Terbatasnya pengetahuan dan kemampuan akan komponen } \\
\text { skill berbicara (pelafalan, tata bahasa, kosakata, kefasihan, dan } \\
\text { pemahaman menyeluruh) }\end{array}$ & 41 & 93.2 \\
\hline 3 & $\begin{array}{l}\text { Terbatasnya waktu persiapan yang diberikan untuk memjawab } \\
\text { pertanyaan }\end{array}$ & 39 & 88.6 \\
\hline 4 & Rasa gugup yang muncul & 34 & 77.3 \\
\hline 5 & Kurangnya rasa percaya diri berbahasa Inggris & 21 & 47.7 \\
\hline 6 & Adanya rasa malu berbahasa Inggris & 20 & 45.5 \\
\hline 7 & Kurangnya pemahaman akan instruksi dan/atau pertanyaan & 17 & 38.6 \\
\hline
\end{tabular}

Sumber: Data Penelitian Tahun 2019

Dari evaluasi yang dilakukan setelah simulasi TEVocS, kurangnya latihan berbicara menggunakan bahasa Inggris menjadi faktor yang paling mempengaruhi mahasiswa program studi Bahasa Korea menjawab soal pada speaking section TEVocS. Terbatasnya pengetahuan dan kemampuan akan komponen yang mendukung skill berbicara seperti pelafalan, tata bahasa, kosakata, kefasihan, dan pemahaman menyeluruh terkait konteks yang dibawakan juga dapat dikatakan sangat mempengaruhi kesulitan mahasiswa program studi Bahasa Korea dalam menjawab soal speaking section TEVocS. Masing-masing dari kedua faktor yang paling menyebabkan mereka kesulitan ini dirasakan oleh lebih dari 90\% responden. Hal ini dikarenakan porsi mata kuliah Bahasa Inggris di program studi terkait memang terbatas pada dua semester di awal studi mereka. 
Terbatasnya waktu persiapan yang diberikan untuk menjawab pertanyaan menjadi faktor ketiga yang paling banyak dirasakan menyulitkan mahasiswa program studi Bahasa Korea dalam menjawab soal speaking section TEVocS. Seperti yang telah disebutkan pada uraian sebelumnya, pada speaking section TEVocS peserta tes diberi waktu 60 detik untuk mempoersiapkan jawaban mereka, baik untuk Describing Picture, Giving Opinion, maupun Answering Question Based on Information Provided. Waktu 60 detik ini kemungkinan besar akan dianggap relatif kurang jika peserta tes tidak terbiasa menggunakan bahasa Inggris karena selain harus memikirkan jawabab atas pertanyaan, peserta tes harus dapat mentransfer jawaban mereka menggunakan bahasa Inggris.

Faktor terbatasnya waktu untuk mempersiapkan jawaban kemudian dapat menyebabkan peserta tes, atau khususnya dalam penelitian ini mahasiswa program studi Bahasa Korea, merasa gugup ketika harus menjawab soal secara lisan menggunakan bahasa Inggris. Ketika mereka belum selesai memikirkan jawaban mereka secara utuh, kemungkinan besar pesserta tes akan gugup ketika menjawab soal secara lisan. Kegugupan ini kemudian memperburuk performa mereka. Hal ini mungkin berupa ucapan yang terbata-bata, banyaknya jeda di antara kalimat yang diucapkan, atau bahkan hilangnya ide yang tadinya sudah tersusun di benak mereka.

Kurangnya rasa percaya diri dan masih adanya rasa malu berbahasa Inggris menjadi faktor lain yang juga menyebabkan mahasiswa program studi Bahasa Korea merasa kesulitan menjawab soal speaking section TEVocS. Kedua hal ini besar kemungkinan disebabkan anggapan mereka bahwa mereka belum memiliki latar belakang kemampuan bahasa Inggris yang cukup untuk dapat berbicara dalam bahasa Inggris dengan baik. Hal ini sebetulnya tidak perlu dirasakan karena seluruh mahasiswa program studi Bahasa Inggris sudah mendapatkan materi bahasa Inggris dari pendidikan formal selama sepuluh tahun lebih sejak mereka masuk Sekolah Dasar. Mereka hanya perlu memperbanyak latihan dan menambah motivasi mereka dalam menggunakan bahasa Inggris secara aktif.

Faktor selanjutnya yang dirasakan masih menyulitkan mahasiswa program 
studi Bahasa Korea dalam menjawab soal speaking section TEVocS adalah kurangnya pemahaman akan instruksi dan/atau pertanyaan pada bagian tersebut. Faktor ini masih dirasa menyulitkan oleh lebih dari sepertiga responden, tepatnya 17 dari 44 total mahasiswa program studi Bahasa Korea yang mengikuti simulasi TEVocS. Hal ini disebabkan oleh masih belum familiarnya mahasiswa program studi Bahasa Korea akan TEVocS itu sendiri termasuk jenis-jenis pertanyaan yang ada di tiap bagian yang diujikan.

Selain faktor-faktor yang telah disebutkan, responden merasa masih ada beberapa faktor lain yang juga menyebabkan mereka kesulitan menjawab soal pada speaking section TEVocS. Faktorfaktor ini ada yang berupa faktor internal atau yang berasal dari diri mahasiswa program studi Bahasa Korea sendiri. Faktor-faktor internal di antaranya seperti terlalu berfokus pada durasi waktu yang diberikan sehingga terbelit-belit ketika berbicara dan merasa bahwa mereka kurang dapat berpikir kritis dalam waktu singkat. Di sisi lain, faktor-faktor eksternal yang disebutkan seperti suasana ketika tes yang kurang kondusif dirasa mengganggu konsentrasi ketika menyampaikan jawaban secara lisan. Yang menarik dari temuan ini adalah sejumlah mahasiswa program studi Bahasa Korea yang mengaku kesulitan memproduksi kalimat berbahasa Inggris karena terpengaruh bahasa lain yang sedang mereka pelajari. Ketika mereka ingin mengutarakan suatu kata dalam bahasa Inggris, justru kata dalam bahasa Korea-lah yang seringkali muncul di pikiran mereka. Hal ini seringkali terjadi pada seorang penutur lebih dari satu bahasa (Heredia dan Altarriba, 2001); (BasnightBrown dan Altarriba, 2007); (Sitaram, dkk., 2019).

\section{Kesimpulan}

Dari penelitian yang dilakukan dengan 44 mahasiswa program studi Bahasa Korea Sekolah Vokasi UGM, sebanyak 93.2\% atau tepatnya 41 mahasiswa mengaku kesulitan menjawab soal TEVocS secara umum. Sebanyak $72.7 \%$ atau tepatnya 32 mahasiswa menganggap listening section TEVocS sulit. Selanjutnya, 93.2\% atau tepatnya 41 mahasiswa menganggap speaking section TEVocS sulit. Temuan ini menunjukkan bahwa hampir seluruh mahasiswa program studi Bahasa Korea 
masih merasa kesulitan menjawab soalsoal dalam TEVocS, baik pada listening section maupun pada speaking section.

Faktor-faktor yang umumnya menyebabkan seseorang kesulitan menjawab soal listening pada English Proficiency Test dianggap ikut berpengaruh terhadap performa mahasiswa program studi Bahasa Korea saat menjawab soal pada listening section TEVocS. Faktorfaktor tersebut antara lain: ucapan penutur yang relatif cepat (100\%); aksen/dialek penutur (88.6\%); lemahnya kemampuan berkonsentrasi (81.8\%); suara di sekeliling yang mengganggu (81.8\%);keterbatasan kosakata bahasa Inggris (77.3\%); waktur merespon atau menjawab yang relatif singkat (77.3\%); informasi yang terlalu banyak dalam waktu singkat (75\%); kualitas rekaman/audio (65.9\%); kekurangpahaman akan topik yang dibicarakan (56.8\%); daya ingat yang lemah (52.3\%); dan kondisi fisik yang kurang baik (32.6\%). Selain faktorfaktor tersebut, audio yang hanya diputar sekali dan kurangnya persiapan juga menyebabkan mahasiswa program studi Bahasa Korea merasa kesulitan menjawab soal listening section TEVocS.
Selanjutnya, terdapat pula beberapa faktor yang menyebabkan mahasiswa program studi Bahasa Korea merasa kesulitan menjawab soal TEVocS. Faktorfaktor ini antara lain: kurangnya latihan berbicara menggunakan bahasa Inggris (97.7\%); terbatasnya pengetahuan dan kemampuan akan komponen skill berbicara (93.2\%); terbatasnya waktu persiapan yang diberikan untuk menjawab pertanyaan (88.6\%); rasa gugup yang muncul (77.3\%); kurangnya rasa percaya diri berbahasa Inggris (47.7\%); adanya rasa malu berbahasa Inggris (45.5\%); dan kurangnya pemahaman akan instruksi dan/atau pertanyaan (38.6\%). Selain faktorfaktor tersebut, masih ada faktor lain yang disebutkan mahasiswa, seperti terlalu berfokus pada durasi sehingga terbelitbelit ketika berbicara, merasa kurang dapat berpikir kritis, suasana tes yang kurang kondusif hingga dirasa mengganggu konsentrasi, hingga kesulitan memproduksi kalimat berbahasa Inggris yang baik karena terpengaruh bahasa lain yang sedang mereka pelajari.

\section{Daftar Pustaka}

Alqahtani, Mofareh. (2015). The Importance of Vocabulary in Language Learning and How to be Taught. International 
Journal of Teaching and Education, 3(3), 21-34.

Bingol, M.A., Celik, B., Yidliz, N., \& Mart, C.T. (2014). Listening Comprehension Difficulties Encountered by Students in Second Language Learning Class. Journal of Educational and Instructional Studies in the World, 4(4), 1-6.

Basnight-Brown, D.M. \& Altarriba, J. (2007). Code-Switching and Code-Mixing in Bilinguals: Cognitive, Developmental, and Empirical Approaches. Speech and Language Disorders in Bilinguals. 69-89.

Chairuddin \& Ulfa, M. (2018). Students Difficulties in Passing Listening Section in TOEFL Prediction Test. Seuneubok Lada: Jurnal Ilmu-Ilmu Sejarah, Sosial, Budaya, dan Kependidikan. 5(1), 16-27.

Halim, N. \& Ardiningtyas, S.Y. (2018). Difficulties Faced by the Students in Answering TOEFL Test Questions. ETERNAL (English Teaching, Learning, and Research Journal), 4(2), 219-231.

Heredia, R.R. \& Altarriba, J. (2001). Bilingual Language Mixing: Why Do Bilinguals Code-Switch? Current Directions in Psychological Science. 10(5).

Hermayawati. (2010). Analisis Kesulitan Belajar Bahasa Inggris Mahasiswa. Jurnal Sosio-Humaniora, 1(1), 1-14.

Lubis, L.R., Irmayana, A., \& Nurbaidah, N. (2019). Analisis Faktor Kesulitas Mahasiswa IPTS dalam Menyelesaikan Soal-soal TOEFL. Prosiding Seminar Nasional Multidisiplin Ilmu Universitas Asahan, 380-387.

Maizarah. (2019). Analysis of Common Difficulties in TOEFL Reading Comprehension (A Case Study on the Second Semester Students of English Study Program Islamic University of Indragiri). English Journal of Indragiri (EJI), 3(2), 99106.
Meilinda, L. \& Yuliah, S. (2019). Kesulitan Menyimak dan Strategi Mahasiswa dalam Memahami Bagian Listening Comprehension padaTes TOEIC. Jurnal Bahasa Inggris Terapan, 5(1), 34-51.

Rusmala, M. (2018). Peran Mata Kuliah Bahasa Inggris dalam Pendidikan Vokasi di STKOM Sapta Computer Kalsel. Prosiding Seminar Nasional Pendidikan, 201-2016.

Sari, Y.I.H. (2017). Proses Pembuatan Item Tes OLIVE, Online Listening for Individual Practice. Jurnal Lingua Aplicata, 1(1), 84-103.

Sekolah Vokasi Universitas Gadjah Mada. (2015). TEVocS User Guide. . (2015)@. TEVocS Practice Test 1.

- (2017). Keputusan Dekan Sekolah Vokasi Universitas Gadjah Mada Nomor 10/UN1.SV/SK/2017 tentang Persyaratan Kelulusan Bagi Mahasiswa Sekolah Vokasi Universitas Gadjah Mada. . (2018). Video Pengenalan TEVocS. [Video]. Yogyakarta: Vocational Development Center Sekolah Vokasi UGM dan Whale Studios. . (2019). Yuk Kenalan dengan TEVocS. [Video]. Yogyakarta: Sekolah Vokasi.

Sitaram, S., Chandu, K.R., Rallabandi, S.K., \& Black, A.W. (2019). A Survey of Code-switched Speech and Language Processing. arXiv preprint. arXiv: 1904.00784V2 [cs.CL].

Wienanda, W.K., Handayani, A., \& Permatasari, A.N. (2018). Pengembangan Video Pembelajaran Mata Kuliah Tata Bahasa I untuk Mahasiswa Program Studi Diploma Bahasa Inggris. Unpublished Project Report.

Wurianto, A.B. (2018). Pengembangan Vokasi Bidang Sosio-Humaniora Menghadapi Revolusi Industri Era 4.0. Prosiding Seminar Nasional Vokasi Indonesia, (1), 89-94. 